\title{
The Complex Attitudes to Alcohol Taxation*
}

\author{
Katarina Nordblom ${ }^{\dagger}$ \\ Working Paper in Economics, no 207
}

May, 2006

\begin{abstract}
Alcoholic beverages are taxed at very different rates across the European Union, which implies extensive cross-border shopping. Therefore, there is an ongoing debate about harmonization of alcohol taxes among countries. Sweden, with a tradition of high alcohol taxes due to public health arguments, has the highest alcohol taxes in the EU. But, because of this, the occurrence and possible problems caused by cross-border shopping are also extensive. Using a questionnaire survey I analyze the attitudes of Swedes' to alcohol taxation and find that these two sides of the coin are important determinants. Many respondents want to decrease the alcohol tax, while some even want to increase it. Those most reluctant to a tax cut are those who regard increased alcohol consumption as a worrying problem and those living in areas where many adults are treated for alcohol related diseases. However, those who support the EU membership are more likely to support a tax cut to harmonize the Swedish tax with those in other EU countries. Those who live in regions where privately imported alcohol is substantial are also more positive toward a tax cut.
\end{abstract}

JEL: F15, H20

Keywords: taxation, cross-border shopping, tax harmonization, attitudes.

\footnotetext{
*This work has benefitted from comments from Fredrik Carlsson, Olof JohanssonStenman, and Peter Martinsson. Financial support from the Malmsten Foundation is greatfully acknowledged.

${ }^{\dagger}$ Department of Economics, Göteborg University, Box 640, SE-405 30 Göteborg, Sweden. E-mail: katarina.nordblom@economics.gu.se.
} 


\section{Introduction}

One tax that during the last decade has been extensively debated in many European countries is the alcohol tax. Since the introduction of the Single Market, cross-border shopping of alcohol has radically increased within the European Union (EU). ${ }^{1}$ This has been one very strong argument for harmonization of alcohol taxes across the EU. In 2003, there was a tax reduction in Denmark as a response to the much lower alcohol taxes in Germany. Estonia, which became an EU member in 2004, has rather low taxes on alcohol, which induced a radical tax cut in Finland in March 2004. Table 1 shows the April 2004 excise taxes on alcohol in the EU countries.

Table 1: Excise duties on wine and spirits in the EU, April 2004, EURO per liter.

\begin{tabular}{|c|c|c|}
\hline & Wine & Spirits \\
\hline Austria & 0.00 & 10.00 \\
\hline Belgium & 0.47 & 16.61 \\
\hline Cyprus & 0.00 & 5.99 \\
\hline Czech Republic & 0.00 & 8.31 \\
\hline Denmark & $0.95-1.42$ & 20.20 \\
\hline Estonia & 0.66 & 9.27 \\
\hline Finland & 2.12 & 28.25 \\
\hline France & 0.03 & 14.50 \\
\hline Germany & 0.00 & 13.03 \\
\hline Great Britain & 2.32 & 27.76 \\
\hline Greece & 0.00 & 9.08 \\
\hline Ireland & 2.73 & 39.25 \\
\hline Italy & 0.00 & 7.30 \\
\hline Latvia & 0.46 & 8.47 \\
\hline Lithuania & 0.43 & 9.27 \\
\hline Luxembourg & 0.00 & 10.41 \\
\hline Malta & 0.00 & 23.32 \\
\hline Netherlands & 0.59 & 17.75 \\
\hline Poland & 0.30 & 9.63 \\
\hline Portugal & 0.00 & 9.63 \\
\hline Slovak Republic & 0.00 & 6.06 \\
\hline Slovenia & 0.00 & 7.07 \\
\hline Spain & 0.00 & 7.40 \\
\hline Sweden & 2.43 & 55.15 \\
\hline Minimum excise duty EU & 0.00 & 5.50 \\
\hline
\end{tabular}

\footnotetext{
${ }^{1}$ The major reason for this cross-border shopping is the large differences in taxation across the Union. The effects of this have been addressed in several papers. E.g. Asplund et al. (2005) study consumer behavior, and Crawford and Tanner (1995) and Crawford et al. (1999) analyze the effects on tax revenue.
} 
Sweden has not only by far the highest taxes on spirits in the EU, but also an extensive cross-border shopping. Since Sweden joined the EU in 1995 and gradually has adopted the union-wide import rules, the share of alcoholic beverages bought abroad has steadily increased. Privately imported alcohol has more than tripled from 0.8 liters to 2.7 liters per person aged 15 and above from 1995 to $2004 .^{2}$ In 2005, a commission of inquiry proposed radical cuts in the Swedish alcohol taxes. ${ }^{3}$ A major reason for this was the increased share of alcohol bought either from other EU countries or from illegal sources, something that a radical tax cut is believed to be able to alleviate.

There are several political motives for alcohol taxation. In American studies the externality motive is pronounced, where especially drunk driving is deterred by taxing alcoholic beverages; see e.g. Kenkel (1996) and Parry and West (2004). Since heavy drinking is also bad for the health of the drinkers, and since people are likely not to be fully aware of the extent of this, there is also a more paternalistic motive for taxation; see e.g. Cook et al. (2005). ${ }^{4}$ The latter motive is the predominant one in Sweden and other Nordic countries, where high excise taxes on alcohol have been a rather successful tool to keep alcohol consumption, and thereby alcohol related health problems at a relatively low level. ${ }^{5}$ A third motive, which should not be neglected, is the fiscal motive. In Sweden the alcohol excise tax brought tax revenues of more than SEK 10 billion in 2004, which was approximately one percent of total tax revenues.

It has been pointed out by Nordlund and Österberg (2000) that it is difficult for a country to maintain high excise taxes on alcohol when it becomes increasingly easy to obtain alcoholic beverages from abroad. Aronsson and Sjögren (2005) have even shown theoretically that in the presence of crossborder shopping, the optimal level of alcohol taxation is lower than the marginal social damage of alcohol, since "border trade erodes the tax base for the alcohol tax". Thus, there are theoretical as well as empirical reasons for decreasing the Swedish alcohol tax, but the downside of a cut could be that a lower tax rate could lead to an increased overall consumption with

\footnotetext{
${ }^{2}$ Trolldal et al. (2005).

${ }^{3}$ SOU (2005).

${ }^{4}$ This public-health motive can also be seen as an externality motive, since alcohol related health problems causes external costs to the health-care sector.

${ }^{5}$ SOU (2005).
} 
more health problems as a consequence. This has also been pointed out by the critics of a potential alcohol tax cut.

When an announcement of a possible alcohol tax cut is made one year before an election, many people regard it as a way to win votes. It is a common view (especially communicated by media) that almost everybody dislikes the alcohol tax (even more so than other taxes). Therefore, many say that decreasing the alcohol tax would be a rather cheap way for the incumbent government to increase its popularity. I study the Swedish people's attitudes towards alcohol taxation and find that opinions are not that simple. It is true that many people want to see the alcohol tax cut, but there is also a non-negligible share who would like the tax to be higher, some even much higher. The attitudes towards the alcohol tax are compared with the attitudes towards the municipal income tax. It turns out that the attitudes towards these two taxes differ a lot. They are on average equally popular or unpopular, but the attitudes towards the alcohol tax are much more diverse. From questionnaires sent out during the fall of 2004, I present information about the attitudes of Swedes to the levels of taxation, and I also analyze what could explain the attitudes.

When analyzing people's attitudes towards the alcohol tax, I conclude that the public health argument is important in explaining the attitudes, as are the issues of cross-border shopping and EU integration. In areas where alcohol related problems are severe, people are reluctant to a decreased alcohol tax. People who are worried about the increased alcohol consumption in society are also more likely to favor increased rather than decreased alcohol taxes. On the other hand, people who consume a lot of alcohol are more likely to support a tax cut, as are those who live in areas rather near the Swedish border where private import constitutes a large share of the total alcohol consumption.

This paper continues as follows. Previous literature in the field of alcohol taxes is reviewed in Section 2. Section 3 describes the data used in the paper, and in Section 4 people's opinions towards the alcohol tax are presented and also compared with the opinions towards the municipal income tax. The attitudinal differences are more thoroughly analyzed in the econometric analysis in Section 5. Finally, Section 6 concludes the paper. 


\section{Previous literature}

Economists have recently started looking at alcohol taxation from both normative and positive angles. Kenkel (2005) analyzes the effects of alcohol taxes on retail prices and finds that the after-tax price increased with more than the tax increase for most alcoholic beverages studied. This would imply that higher alcohol taxes actually discourage excessive drinking, which is supported by Markowitz et al. (2005) who study the effect of alcohol use on risky sexual behavior among teenagers. They find that higher beer taxes would decrease teenage drinking and thereby sexually transmitted diseases. Normative studies have been concerned with the externality from excessive drinking, from e.g. drunk driving, crime, and medical costs. Besides correcting the externality, excise taxes are also advocated from a public health point of view, because drinkers themselves may be unaware of the total consequences of drinking on their own health. Kenkel (1996) concludes that the more uninformed heavy drinkers there are, the higher the optimal tax, in combination with punishments for drunk driving. Also Parry and West (2004) have an externality argument for alcohol taxes, but also stress the possibility to gain tax revenue to enable cuts of other taxes. Cook et al. (2005) stress the public health argument and find that increased alcohol taxes would reduce mortality since excessive drinking would be deterred.

There have also been papers that have analyzed alcohol taxation, specifically in the presence of cross-border shopping. When there is cross-border shopping, one country cannot freely choose excise taxes an alcohol, because these can affect where people choose to make their purchases. According to Nordlund and Österberg (2000), the Nordic countries (that historically have had relatively high alcohol taxes) have acquired problems with unrecorded alcohol consumption (legal as well as illegal). With a more integrated European market it has been difficult to maintain high tax levels. During the last decade, we have actually seen both Finland and Denmark reduce their excise taxes on alcohol. Asplund et al. (2005) is another paper dealing with alcohol consumption and cross-border consumption, studying how alcohol sales in Sweden are affected by price changes in Denmark and Germany. They find that Swedes are very sensitive to price changes abroad, even quite far from the border. Since all alcohol in Sweden is sold by the state retail monopoly and at the same prices throughout the country, this means 
that Swedes are sensitive to the relative price of alcoholic beverages purchased domestically and abroad. Aronsson and Sjögren (2005) show that in the presence of cross-border shopping, alcohol taxation would optimally be lower than in a completely closed economy, and Crawford and Tanner (1995) and Crawford et al. (1999) find circumstances under which reduced alcohol taxation can actually increase tax revenue when there is substantial cross-border shopping.

\section{Data}

In the paper I use data from three sources. The main data set, from which I have opinions and background variables on individual level, is from the 2004 SOM survey, conducted by the SOM Institute (Society, Opinion, Media). ${ }^{6}$ This data is complemented by regional information on alcohol consumption from the Centre for Social Research on Alcohol and Drugs (SoRAD) and by county level data on alcohol related health problems from the Swedish National Institute of Public Health (SNIPH).

In the 2004 SOM survey, a mail questionnaire was sent out in the fall of 2004 to a random sample of 3,000 Swedes aged 15 - 85 whose addresses were collected from the National Register. In total 1,774 individuals returned the questionnaire (net response rate $64 \%$ ) and 1,692 of those had answered at least one of the questions about tax attitudes.

The alcohol consumption data from SoRAD is based on self reported consumption of alcoholic beverages of different kinds and from different sources. This data is collected on a regional basis, where Sweden is divided into seven large regions. In the regressions I include the share of alcohol that was imported (legal as well as illegal) in each region for 2004. In Table 3 the amount of alcohol consumed is presented, in total as well as the privately imported.

From SNIPH I use county level data. ${ }^{7}$ The original data contains the number of men and women per 10,000 who were treated for alcohol related diagnoses as well as the number of boys and girls aged 15-19 per 10,000 who were treated for alcohol poisoning in 2003. In my study I use the mean of men and women in each county as the number of adults treated for alcohol related diagnoses. Similarly, I do not separate between girls and boys, but

\footnotetext{
${ }^{6}$ See http://www.som.gu.se/english.htm for more information about the SOM Institute.

${ }^{7}$ Sweden has 21 counties.
} 
use their mean as the number of alcohol poisoned teenagers. From SNIPH I also use information on drunk driving. For each county, I use the number of reported drunk driving cases per 10,000 inhabitants. The reason why I use data on alcohol related problems for 2003 and not for 2004 is that the 2003 data were available to the public during 2004 when the SOM survey was conducted.

Tables 5 and 6 in the Appendix give more detailed descriptions of the included variables.

\section{People's opinions}

Table 2 presents the attitudes to the alcohol tax and to the municipal income tax. In the questionnaire the following question was posed:

Do you think the following taxes should be increased or decreased?

The answers were then distributed as follows:

Table 2: Attitudes towards two taxes, in percent.

\begin{tabular}{l|cccccc} 
& $\begin{array}{c}\text { Abolish/ } \\
\text { decrease a lot }\end{array}$ & $\begin{array}{c}\text { Decrease } \\
\text { a little }\end{array}$ & $\begin{array}{c}\text { Keep it } \\
\text { unchanged }\end{array}$ & $\begin{array}{c}\text { Increase } \\
\text { a little }\end{array}$ & $\begin{array}{c}\text { Increase } \\
\text { a lot }\end{array}$ & $\begin{array}{c}\text { No } \\
\text { opinion }\end{array}$ \\
\hline Municipal income tax & 8 & 42 & 35 & 5 & 0 & 10 \\
Alcohol tax & 20 & 35 & 25 & 6 & 7 & 7 \\
\hline
\end{tabular}

No of obs. 1,692

More people have an opinion about the alcohol tax than about the municipal income tax, and the attitudes towards the alcohol tax are much more diverse. A $\chi^{2}$ test shows that there are significantly more respondents who have an opinion about the alcohol tax. That the distributions of attitudes towards the two taxes are the same can be rejected by another $\chi^{2}$ test. $^{8}$ Hence, the alcohol tax holds people's attention to a high degree. ${ }^{9}$

\footnotetext{
${ }^{8}$ The $\chi^{2}$ test of how many of the respondents who state that they have no opinion tells that the difference is significant, with a $\chi^{2}$ with one degree of freedom equal to 342 and the $\chi^{2}$ associated with the two distributions has 16 degrees of freedom and equals 151 , which is also strongly significant.

${ }^{9}$ Also Hammar et al. (2006) find that among eleven taxes, the alcohol tax is the one that the fewest people lack opinion about.
} 
The share wanting to abolish or decrease the tax a lot is much higher for the alcohol tax than for the income tax (20\% compared to $8 \%$ ). No one wants the income tax to be very much higher, but $7 \%$ are in favor of a radically increased alcohol tax. The very different nature of the two taxes could perhaps explain the difference. The municipal income tax is a tax used primarily for fiscal and distributional reasons. In most municipalities it is roughly $30 \%$ of gross income, which makes it comprise almost $1 / 3$ of the total tax revenue in Sweden. The alcohol tax is different. It is not a major source of income for the public sector; it brings in about $1 \%$ of the total tax revenue. Nor is it primarily a redistributive tax; there are many indications that excise taxes on alcohol and tobacco are even regressive. ${ }^{10}$ Rather, the main political motive for the alcohol tax is the public health motive, to prevent people from drinking too much. These different tax motives could certainly be one explanation to why the attitudes differ so much between the two taxes. We will look into that more in the econometric analysis.

\subsection{Regional differences}

The main argument for an alcohol tax cut is that taxes higher than those in neighboring countries make people go abroad to purchase their alcoholic beverages if there is an opportunity. The reason why the government regards this as undesirable is twofold: The Swedish state loses both tax revenues and the control over the alcohol consumption. ${ }^{11}$ As the distance to continental Europe varies a lot within Sweden so does the imported share of alcohol. Therefore, the opinion based on this argument could very well vary across the country. SoRAD provides information about privately imported as well as total alcohol consumption for seven regions in 2004 (the two far right columns in Table 3). In Skåne (from where one can easily and quickly travel to continental Europe) $55 \%$ of the consumed alcohol is purchased abroad. In the Halland, Kronoberg, and Blekinge region, which is a bit farther from Denmark and Germany, as much as $57 \%$ is purchased abroad. ${ }^{12}$ This region also has the highest total consumption of alcohol. The farther from the

\footnotetext{
${ }^{10}$ See e.g. Lyon and Schwab (1995).

${ }^{11}$ Crawford and Tanner (1995) and Crawford et al. (1999) analyze the effects of alcohol taxation in the UK after the single European market and discuss how increased or decreased excise taxes on alcohol would affect tax revenues.

${ }^{12}$ Denmark and Germany are the two countries from where most private import comes (Gustafsson and Trolldal, 2004)
} 
border, the less alcohol is imported and in Norrland (the northern part of Sweden) less than $16 \%$ of total alcohol consumed is purchased abroad.

Table 3 about here

As the alcohol tax is a policy tool to mitigate the adverse health effects from alcohol consumption, living in areas where alcohol causes a lot of damage might also affect attitudes towards alcohol taxes. SNIPH provides figures for alcohol related diagnoses on a county level. I use figures on the number of drunk driving cases, on the number of adults treated for alcohol related diagnoses, and of people aged 15-19 treated for alcohol poisoning during 2003 (in the middle columns of Table 3).

The figures for Gotland are the highest in the country for all three categories. One explanation is that this island in the Baltic Sea attracts many summer tourists. Gotland is a popular place for summertime partying, especially among young people. Also in Norrland, a considerably higher proportion of teenagers compared to the Swedish average were treated for alcohol poisoning. In Norrland, however, the number of adults treated for alcohol related diagnoses were lower than the national average. Stockholm had the opposite situation, where a large proportion of adults were treated for alcohol related diagnoses, while less teenagers than average were treated for alcohol poisoning. Counties with overall low shares of health problems related to alcohol are found in the South.

Table 3 is then completed with the opinions about the alcohol tax, by the same regions and counties. Here I restrict the observations to those who actually had an explicit opinion about the alcohol tax. The percent of respondents wanting the alcohol tax to be decreased and increased, respectively, are presented in the first two columns.

We see that the attitudes towards the alcohol tax differ a lot among counties. Looking at Table 3, we see that in the northern parts of Sweden, people are more positive to the alcohol tax than in the rest of the country. In Norrbotten, only $29 \%$ of the respondents wanted a decreased alcohol tax, compared to the country average of $60 \% .20 \%$ of the respondents in Norrbotten wanted the alcohol tax to be increased, which is a significantly larger share than the country average of $13 \%$. On Gotland, the second most positive county, the corresponding figures were 36 and $18 \%$, respectively. Those who are the most negative are found in the Halland, Kronoberg, 
Östergötland and Örebro counties. Hence, it seems that in counties with more alcohol related problems than the national average, people are less prone to advocate a tax cut and more prone to want higher alcohol taxes. When it comes to the distance to continental Europe and the share of alcohol purchased abroad, it also seems like people in areas where foreign alcohol is substantial are more likely than others to regard the alcohol tax as too high.

\section{Probit analysis}

Let us analyze in more detail what explains the attitudes towards the taxes. The appropriate technique for such an analysis is the probit model. The motive for using separate probits instead of an ordered probit is that there might well be differences between people who are in favor of tax cuts and those who want to increase the tax. ${ }^{13}$ I have run probits where the dependent variables are whether one wants to decrease a tax and whether one wants to increase it, respectively. ${ }^{14}$ In the first four columns in Table 4 the results are presented for wanting to decrease and increase the municipal income tax and the alcohol tax, respectively.

The explanatory variables are those that can be assumed to affect attitudes towards taxes generally. Distrust in politicians could be assumed to make people more negative towards taxation. If one distrusts politicians, one is more likely to feel that they should have less influence, which would imply lower taxes. Also general distrust could affect the attitudes towards taxes. I therefore include dummy variables for those distrusting the politicians in the Swedish parliament, and for those distrusting their fellow citizens, respectively. The income level could affect the attitudes, although the direction of the effect is unclear. On the one hand, high-income earners would gain more from lower taxes than would low-income earners, but on the other hand, a tax cut could make a substantial difference for low-income earners, living on the margin. Gemmell et al. (2004) find that high-income earners prefer marginal increases in a consumption tax rather than in the income tax. Income is not a continuous variable in the SOM survey, so I categorize respondents into three groups: low, middle, and high income

\footnotetext{
${ }^{13}$ However, marginal effects from ordered probits give similar results as those reported in Table 4.

${ }^{14}$ In these probits I have only used those respondents who actually had an opinion.
} 
earners. In the regressions middle income earners is the omitted category. ${ }^{15}$ Educational level could influence attitudes through increased knowledge and understanding of the tax system, so I include a dummy for those who have at least some university education. Since media plays an important role in opinion making, I also include a dummy for whether one regularly reads a newspaper (at least six days a week). I control for political sympathies, where default is "other party" (generally left-wing parties). Also gender and age are controlled for, where men and the group aged 50+ are the references. The youngest category are those who are not yet allowed to purchase any alcoholic beverages. ${ }^{16}$

Table 4 about here

When analyzing these probits, we can draw some conclusions. If one does not trust politicians in their tasks, then one is more likely to advocate reduced taxes of both sorts. However, the effects are much stronger for the income tax than for the alcohol tax. One explanation could be that income tax is primarily a source of revenue for the public sector, while the primary goal for taxing alcohol is to prevent people from drinking too much (although it also generates some revenue). If one does not trust the politicians to do a good job in administrating tax revenue, then one should prefer a reduced income tax to a reduced alcohol tax. The dummy variable for distrusting people in general has no impact at all on the attitudes to the municipal income tax. However, respondents who distrust people in general are more likely to be in favor of an increased alcohol tax. One possible consequence of general distrust is that it makes one believe that people drink too much and that this would be discouraged by higher taxes. Women are less inclined than men to favor a higher municipal income tax, while the opposite is true for an alcohol tax. Respondents with a high level of education - at least some studies at the university level - are less likely to demand tax cuts and more likely to be in favor of raised taxes. The only effect from income is that low income earners are more likely to support a lower income tax. People who read a newspaper at least six days a week are less likely to advocate cuts of any of the two taxes. Age does not seem to matter more than marginally for the attitudes towards the municipal income tax. However, teenagers are

\footnotetext{
${ }^{15}$ See the Appendix for a definition of high and low income earners.

${ }^{16}$ In Sweden you have to be 20 years old to shop at the state owned retail monopoly.
} 
reluctant to decrease and eager to increase the tax on alcohol.

When it comes to political sympathies, the effects are less significant for the alcohol tax than for the municipal income tax. That the omitted category is "other party," which is typically a left-wing choice, explains why sympathies for the parties to the left are insignificant. These are included in the regressions, but not reported in Table 4. The three more rightwing parties, the Liberal Party (fp), the Christian Democrats (kd) and the Conservatives $(\mathrm{m})$ all proclaim lower income taxes than the other parties. Sympathizing with any of these parties has a significant impact on the income tax attitude. (m) is the most right-wing party, showing the strongest effects. The primary reason for the alcohol tax is not to support the public sector with tax revenue. Ideological differences in attitudes to the size of the public sector in general therefore have less impact on the attitude to the alcohol tax.

As mentioned above, the tax on alcohol is different from the tax on income. Therefore the attitudes could also be affected by other variables, which are more specifically connected to alcohol itself. Accordingly, I include some extra variables in a second model specification, of which the results can be found in the fifth and sixth columns in Table 4. These are variables that are likely to capture the specific features of the alcohol tax. I include a dummy for whether one is worried about the increased alcohol consumption in society. I also use the county level variables for alcohol related problems presented in Table 3: the number of adults treated for alcohol related diseases, the number of 15-19 year olds treated for alcohol poisoning and the number of reported cases of drunk driving, all measured per 10,000 inhabitants.

The arguments for decreased alcohol taxation are mainly tax harmonization within the EU and that lower taxes would encourage people to make their purchases in Sweden instead of abroad. I therefore include a dummy for whether one generally approves of the Swedish EU membership. One might believe that respondents who are more satisfied with the EU membership also advocate a reduced alcohol tax to a larger extent than others. Different regions are differently affected by cross-border shopping, so this argument could differ in importance among different regions. This was suggested in Section 4.1, and Asplund et al. (2005) find that price elasticities fall with the increasing distance to Malmö, with the highest elasticities for 
regions less than $200 \mathrm{~km}$ away, and much lower for distances of more than $460 \mathrm{~km}$. I have constructed two variables aiming to capture this; one is the Near import which is the regional share of imported alcohol if one lives closer than $200 \mathrm{~km}$ to Malmö, and the second is Half-distance import which is the share of imported alcohol between 200 and $500 \mathrm{~km}$ from Malmö. To control for self-interest I also include a dummy for whether one drinks alcohol at least once a week.

From the results it is clear that most of these variables have an impact on the attitudes to alcohol taxation. We can also see that when including the attitude variables, the gender effect disappears. Those who worry about increased alcohol consumption in society and those living in counties with many adults treated for alcohol related diseases are less likely to support a tax reduction. There are, however, no significant effects from drunk driving or from alcohol poisoning among teenagers. One explanation could be that adults are sensitive to the tax and would buy more alcohol with a lower tax rate. Teenagers, on the other hand, always get their alcoholic beverages illegally (and sometimes home-distilled or smuggled). This makes it likely that people consider teenagers' alcohol related problems to be better solved by policies other than the alcohol tax. The same goes for drunk driving. What is pointed out in the public debate is rather that more police resources are needed to prevent drunk driving; this is not a problem that people connect with alcohol taxation.

When it comes to tax harmonization within the EU to decrease crossborder shopping, those who support the Swedish EU membership are more likely to support a tax cut. For those living closest to the border, the imported share of alcohol has less impact than for those living between 200 and $500 \mathrm{~km}$ from the border. It could very well be the case that those living very close to the border are less sensitive to the Swedish tax since at least spirits would still be cheaper abroad even with a tax cut, implying that they would go to Denmark or Germany to make their purchases anyway. Those living a bit farther away, on the other hand, have higher travel costs to get to continental Europe. ${ }^{17}$ Therefore they would be more likely to make their purchases in Sweden if the tax was radically reduced, which could explain why they are more supportive of a tax cut than people in other areas. This could be seen as a self-interest motive. Another indication of self-interest

\footnotetext{
${ }^{17}$ Asplund et al. (2005).
} 
is that those who drink alcohol at least once a week are more inclined to advocate a lower alcohol tax.

\section{Discussion and Conclusion}

In this paper I have analyzed the attitudes towards the alcohol tax in Sweden, the country within the European Union with by far the highest tax rates on alcohol. The Swedish government has announced that a decreased alcohol excise tax may come about, the main motivation for this being the extensive cross-border shopping. Since Sweden joined the EU in 1995 the cross-border shopping has radically increased. Alcohol purchased abroad has more than tripled from 0.8 liters of pure alcohol per person aged 15 and above in 1995 to 2.7 liters in 2004. ${ }^{18}$ However, total alcohol consumption has also increased from 7.8 to 10.4 liters during the same period, and the major reason for having alcohol taxation at all is to prevent people from drinking too much and thereby to mitigate alcohol related problems. This trend would therefore speak against a tax cut. Hence, we have two trends giving opposite implications for the level of alcohol taxation, which are also reflected in people's attitudes towards this tax.

Using Swedish survey data from the fall of 2004, I find that $60 \%$ of respondents would like the alcohol tax to be lower, $27 \%$ would like it to remain unchanged and $13 \%$ would like it to be higher. This makes the attitudes towards the alcohol tax more diverse than those towards e.g. the municipal income tax.

The attitudes vary greatly across the country, where citizens in regions with a lot of private import are more supportive of lower taxes than others. On the other hand, in areas with a lot of alcohol related problems people are more reluctant to a tax cut and are more likely to support higher tax rates. Approving of the Swedish membership in the EU makes people more likely to want a tax cut. Thus, it seems like both the public health argument and the EU integration argument have impact on the attitudes to alcohol taxation.

Hence, a reduced alcohol excise tax would be supported by a majority of Swedes, especially among those living in the southern parts where there is extensive cross-border shopping. The $45 \%$ who support the Swedish mem-

\footnotetext{
${ }^{18}$ Trolldal et al. (2005).
} 
bership in the EU are also more likely to support a tax cut in order to harmonize the Swedish alcohol taxation with those of other European countries. People living in the North, on the other hand, are reluctant to such a tax cut, as are many young people and those who regard increased alcohol as a worrying trend in society.

From this we learn that the attitudes to alcohol taxation are complex and that there are many issues that have to be taken into account for full consensus to be reached about harmonization of alcohol taxes within the EU.

\section{References}

Aronsson, T. and Sjögren, T. (2005). Externalities, border trade and illegal production: An optimal tax approach to alcohol policy. Umeå Economic Studies 654, Umeå University.

Asplund, M., Friberg, R., and Wilander, F. (2005). Demand and distance: Evidence on cross-border shopping. SSE/EFI Working Paper Series in Economics and Finance 587, Stockholm School of Economics.

Cook, P. J., Ostermann, J., and Sloan, F. A. (2005). The net effect of an alcohol tax increase on death rates in middle age. The American Economic Review, 95:278-281.

Crawford, I., Smith, Z., and Tanner, S. (1999). Alcohol taxes, tax revenues and the single European market. Fiscal Studies, 20:287-304.

Crawford, I. and Tanner, S. (1995). Bringing it all back home: Alcohol taxation and cross-border shopping. Fiscal Studies, 16:94-114.

Gemmell, N., Morrissey, O., and Pinar, A. (2004). Tax perceptions and preferences over tax structure in the United Kingdom. The Economic Journal, 114:F117-F138.

Gustafsson, N.-K. and Trolldal, B. (2004). Svenska folkets alkoholkonsumtion under år 2003 (swedish people's alcohol consumption during 2003). Research Report, 26, SoRAD, Stockholm University. 
Hammar, H., Jagers, S., and Nordblom, K. (2006). What explains attidudes towards tax levels? A multi tax comparison. Mimeo.

Kenkel, D. S. (1996). New estimates of the optimal tax on alcohol. Economic Inquiry, XXXIV:296-319.

Kenkel, D. S. (2005). Are alcohol tax hikes fully passed through to prices? Evidence from alaska. The American Economic Review, 95:273-277.

Lyon, A. B. and Schwab, R. M. (1995). Consumption taxes in a life-cycle framework: Are sin taxes regressive? The Review of Economics and Statistics, LXXVII:389-406.

Markowitz, S., Kaestner, R., and Grossman, M. (2005). An investigation of the effects of alcohol consumption and alcohol policies on youth risky sexual behaviors. The American Economic Review, 95:263-266.

Nordlund, S. and Österberg, E. (2000). Unrecorded alcohol consumption: its economics and its effects on alcohol control in Nordic countries. Addiction, 95:S551-S564.

Parry, I. W. and West, S. E. (2004). Fiscal and externality arguments for alcohol taxation. National Tax Association Proceedings, pages 12-18.

SOU (2005). Gränslös utmaning - alkoholpolitik i ny tid (Alcohol policy in a new era). SOU 2005:25, the Government Official Reports.

Trolldal, B., Boman, U., and Gustafsson, N.-K. (2005). Alkoholkonsumtionen och dess olika delmängder 2004 (Alcohol consumption and and its different subsets 2004). Research Report 28, SoRAD, Stockholm University. 
Table 3: Opinions, alcohol related problems, and consumption, by regions.

\begin{tabular}{|c|c|c|c|c|c|c|c|}
\hline & \multicolumn{2}{|c|}{ Opinions } & \multicolumn{3}{|c|}{ Alcohol related problems } & \multicolumn{2}{|c|}{ Alcohol consumptior } \\
\hline & Decrease $^{a}$ & Increase $^{a}$ & Drunk driving $^{b}$ & Adults $^{c}$ & $15-19$ years $^{d}$ & Total $^{e}$ & Imported $^{e}$ \\
\hline Skåne & 66 & 11 & 15.43 & 17.56 & 16.49 & 10.8 & 5.9 \\
\hline Rest of the South & 67 & 10 & & & & 11.7 & 6.7 \\
\hline Blekinge & 61 & 13 & 18.34 & 18.89 & 13.90 & & \\
\hline Halland & 71 & 10 & 16.75 & 15.72 & 18.83 & & \\
\hline Kronoberg & 67 & 11 & 17.64 & 18.04 & 10.60 & & \\
\hline Västra Götaland & 59 & 13 & 15.87 & 21.14 & 20.98 & 10.9 & 4.3 \\
\hline Rest of Götaland & 62 & 13 & & & & 9.2 & 3.3 \\
\hline Gotland & 36 & 18 & 25.03 & 30.32 & 44.83 & & \\
\hline Jönköping & 55 & 17 & 13.45 & 22.93 & 18.23 & & \\
\hline Kalmar & 64 & 13 & 16.77 & 21.48 & 25.77 & & \\
\hline Östergötland & 72 & 9 & 15.98 & 17.64 & 26.48 & & \\
\hline Stockholm & 56 & 13 & 19.09 & 27.64 & 12.24 & 11.2 & 2.3 \\
\hline Rest of Svealand & 62 & 16 & & & & 10.1 & 3.0 \\
\hline Dalarna & 58 & 18 & 17.72 & 24.04 & 22.73 & & \\
\hline Södermanland & 64 & 13 & 14.64 & 19.62 & 22.35 & & \\
\hline Uppsala & 64 & 11 & 14.71 & 22.30 & 18.70 & & \\
\hline Värmland & 65 & 12 & 17.47 & 14.39 & 20.49 & & \\
\hline Västmanland & 53 & 19 & 20.77 & 20.63 & 18.48 & & \\
\hline Örebro & 69 & 12 & 16.06 & 24.40 & 19.88 & & \\
\hline Norrland & 47 & 14 & & & & 8.9 & 1.4 \\
\hline Gävleborg & 63 & 12 & 14.52 & 18.23 & 27.22 & & \\
\hline Jämtland & 44 & 15 & 21.24 & 14.82 & 37.53 & & \\
\hline Norrbotten & 29 & 20 & 22.02 & 20.22 & 30.16 & & \\
\hline Västerbotten & 53 & 14 & 15.82 & 13.77 & 22.51 & & \\
\hline Västernorrland & 53 & 11 & 18.71 & 19.87 & 41.88 & & \\
\hline The whole country & 60 & 13 & 17.05 & 21.07 & 20.11 & 10.4 & 3.5 \\
\hline
\end{tabular}

${ }^{a}$ The percent of respondents with an opinion wanting the alcohol tax to be decreased or increased.

${ }^{b}$ Number of reported cases of drunk driving per 10,000 (SNIPH).

${ }^{c}$ Number of adults treated for alcohol related diagnoses per 10,000 (mean of men and women) (SNIPH).

${ }^{d}$ Number of 15-19 year olds treated for alcohol poisoning per 10,000 (mean of boys and girls) (SNIPH).

${ }^{e}$ Liters of pure alcohol per inhabitant aged 15 or above (SoRAD). 


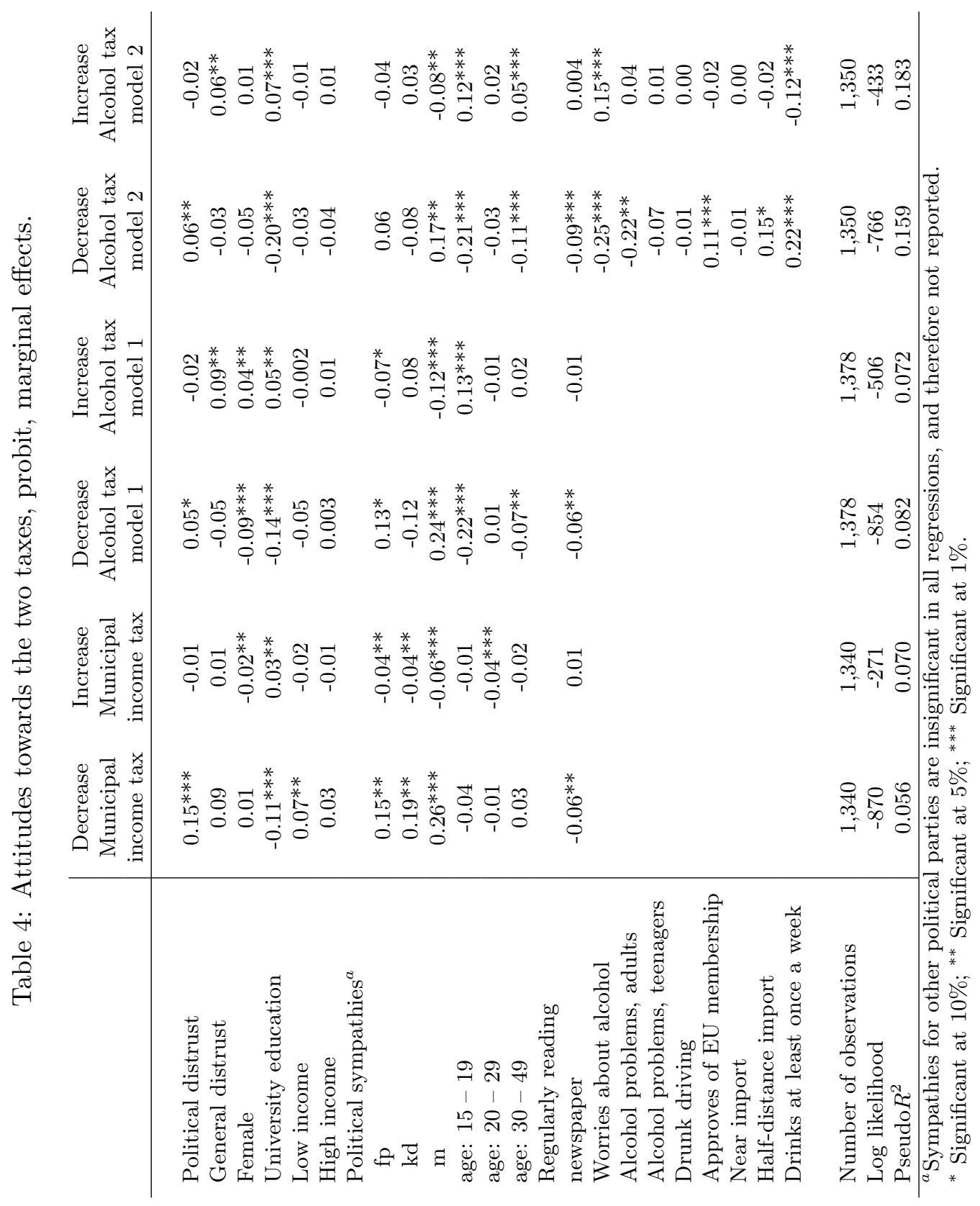




\title{
Appendix: Summary statistics
}

\author{
Table 5: Variable definitions
}

\begin{tabular}{|c|c|}
\hline Variable & Variable definition \\
\hline Political distrust & 1 if one has little or no confidence in politicians in Parliament \\
\hline General distrust & 1 if one does not trust people in general \\
\hline Female & \\
\hline University education & 1 if the individual has at least some university studies \\
\hline Low income & $\begin{array}{l}1 \text { if hh income is less than SEK } 300,000 \text { in a two-earner hh and } \\
\text { less than SEK 100,000 for a sole income earner. }\end{array}$ \\
\hline High income & $\begin{array}{l}1 \text { if hh income exceeds SEK } 600,000 \text { in a two-earner hh and } \\
\text { SEK 400,000 for a sole income earner. }\end{array}$ \\
\hline $\begin{array}{l}\text { Political sympathies } \\
\text { v } \\
\mathrm{mp} \\
\mathrm{s} \\
\mathrm{c} \\
\mathrm{fp} \\
\mathrm{kd} \\
\mathrm{m}\end{array}$ & Dummies indicating the preferred party, ranging from left to right. \\
\hline Other party & Most often a left-wing party \\
\hline $\begin{array}{l}\text { Supports EU membership } \\
\text { age: } 15-19 \\
\text { age: } 20-29 \\
\text { age: } 30-49\end{array}$ & 1 if one approves of the Swedish EU membership. \\
\hline $\begin{array}{l}\text { Regularly reading } \\
\text { newspaper }\end{array}$ & 1 if one reads a newspaper at least six days a week \\
\hline Worries about alcohol & 1 if one states that increased alcohol consumption is a worrying issue for society \\
\hline Drinks at least once a week & 1 if one states that one drinks alcohol at least once a week \\
\hline Alcohol problems, adults & The number of adults treated for alcohol related diseases, by 10,000 in the county. \\
\hline Alcohol problems, teenagers & $\begin{array}{l}\text { The number of people aged } 15-19 \text { treated for alcohol poisoning, } \\
\text { by } 10,000 \text { in the county. }\end{array}$ \\
\hline Drunk driving & The number of reported cases of drunk driving in the county, by 10,000 inhabitants. \\
\hline Near import & $\begin{array}{l}\text { The share of total alcohol consumption in the region that is imported } \\
\text { if one lives less than } 200 \mathrm{~km} \text { from Malmö. }\end{array}$ \\
\hline Half-distance import & $\begin{array}{l}\text { The share of total alcohol consumption in the region that is imported } \\
\text { if one lives at a distance between } 200 \mathrm{~km} \text { and } 500 \mathrm{~km} \text { from Malmö. }\end{array}$ \\
\hline
\end{tabular}


Table 6: Summary statistics

\begin{tabular}{ll} 
Variable & Mean \\
\hline Political distrust & 0.30 \\
General distrust & 0.06 \\
Female & 0.48 \\
University education & 0.31 \\
Low income & 0.23 \\
High income & 0.15 \\
Political sympathies & \\
v & 0.10 \\
mp & 0.05 \\
s & 0.35 \\
c & 0.07 \\
fp & 0.11 \\
kd & 0.05 \\
m & 0.23 \\
Other party & 0.05 \\
Supports EU membership & 0.45 \\
age: 15 - 19 & 0.07 \\
age: 20 - 29 & 0.14 \\
age: 30 - 49 & 0.34 \\
Regularly reading & 0.63 \\
newspaper & \\
Worries about alcohol & 0.22 \\
Drinks at least once a week & 0.37 \\
Alcohol problems, adults & 21 \\
Alcohol problems, teenagers & 20 \\
Drunk driving & 17 \\
Near import & 0.10 \\
Half-distance import & 0.13 \\
\hline Number of observations & 1,350 \\
&
\end{tabular}

